\title{
Aberrant expression of miR-21, miR-376c and miR-145 and their target host genes in Merkel cell polyomavirus-positive non-small cell lung cancer
}

\author{
Ismini Lasithiotaki ${ }^{1,2}$, Eliza Tsitoura ${ }^{2,3}$, Anastasios Koutsopoulos $^{4}$, Eleni Lagoudaki ${ }^{4}$, \\ Chara Koutoulaki², George Pitsidianakis ${ }^{1}$, Demetrios A. Spandidos ${ }^{3}$, Nikolaos M. \\ Siafakas $^{1}$, George Sourvinos ${ }^{3, *}$ and Katerina M. Antoniou ${ }^{1,2, *}$ \\ ${ }^{1}$ Department of Thoracic Medicine, University Hospital, Medical School, University of Crete, Heraklion 71110, Greece \\ ${ }^{2}$ Laboratory of Cellular and Molecular Pneumonology, Medical School, University of Crete, Heraklion Crete 71110, Greece \\ ${ }^{3}$ Laboratory of Clinical Virology, Medical School, University of Crete, Heraklion Crete 71110, Greece \\ ${ }^{4}$ Department of Pathology, Medical School, University of Crete, Heraklion Crete 71110, Greece \\ *These authors have contributed equally to this work \\ Correspondence to: George Sourvinos, email: sourvino@med.voc.gr \\ Keywords: merkel cell polyomavirus; non-small cell lung cancer; microRNAs; signalling pathways \\ Received: April 23, $2016 \quad$ Accepted: July 19, $2016 \quad$ Published: August 11, 2016 \\ Copyright: Lasithiotaki et al. This is an open-access article distributed under the terms of the Creative Commons Attribution License \\ 3.0 (CC BY 3.0), which permits unrestricted use, distribution, and reproduction in any medium, provided the original author and \\ source are credited.
}

\section{ABSTRACT}

Merkel Cell Polyoma Virus (MCPyV) infection has been associated with non-small cell lung cancer (NSCLC). Viruses can manipulate cellular miRNAs or have a profound impact on cellular miRNA expression to control host regulatory pathways. In this study, we evaluated the expression profiles of cancer-associated and virally affected host microRNAs miR-21, miR-145, miR-146a, miR-155, miR-302c, miR-367 and miR-376c in a series of NSCLC tissue samples as well as in samples from "healthy" sites, distant from the tumour region that were either positive or negative for MCPyV DNA. miR-21 and miR-376c were significantly upregulated whereas miR-145 was significantly downregulated in the MCPyV+ve samples compared to the MCPyV-ve tumour samples. Overall, miR-21 and miR-376c expression was higher in tumour compared to healthy tissue samples. No association was observed between the miR-155, miR-146a, miR-302c and miR-367 levels and the presence of MCPyV. The expression of miR-21 target genes (Pten, Bcl-2, Daxx, Pkr, Timp3), miR-376c (Grb2, Alk7, Mmp9) and miR-145 (Oct-4, Sox2, Fascin1) and their associated pathways (Braf, Akt-1, Akt-2, Bax, Hif1a, p53) was altered between MCPyV+ve tumor samples and their corresponding controls. These results show a novel association between miR-21, miR376c and miR-145 and their host target genes with the presence of MCPyV, suggesting a mechanism of virus-specific microRNA signature in NSCLC.

\section{INTRODUCTION}

Lung cancer remains the leading cause in cancerrelated mortality in both males and females. Approximately $85 \%$ of lung tumors are non-small cell lung cancer (NSCLC), including adenocarcinoma, squamous cell carcinoma and large cell carcinoma [1]. Although the majority of lung cancer patients are smokers, only a minority among smokers will develop this disease, strongly suggesting that additional environmental determinants including virus infections, in a background of genetic susceptibility, drive disease initiation and progression [2].

The accumulation of genetic and epigenetic events in the respiratory epithelium is essential for lung carcinogenesis [3]. In particular, microRNAs (miRNAs) have been shown to be commonly dysregulated in lung cancer [4]. MicroRNAs, short, non-coding RNA molecules, are key regulators of transcription regulation and it is currently appreciated that they participate in tumorigenesis by regulating the expression of oncogenes 
Table 1: The clinicopathological characteristics and histological NSCLC types of all patients

\begin{tabular}{lccc}
\hline Characteristics & MCPyV-positive & MCPyV-negative & P-value \\
\hline Number & 8 & 16 & \\
Age $^{*}$ & $68.00 \pm 8.21$ & $62.82 \pm 11.63$ & NS \\
Sex (male/female) ${ }^{* *}$ & $7 / 1$ & $14 / 2$ & NS \\
Non-smokers** $^{*}$ & 1 & 1 & NS \\
Smokers $^{* *}$ & 6 & 8 & NS \\
Ex-smokers* $^{*}$ & 1 & 7 & NS \\
Adenocarcinoma & 5 & 10 & \\
Squamous & 2 & 5 & \\
Large Cell Undifferentiated & 1 & 1 & \\
\hline
\end{tabular}

Values are expressed as means $\pm \mathrm{SD}$ (standard deviation).

${ }^{*} t$-test; $P<0.05$ is considered statistically significant.

${ }^{* *} \chi^{2}$ test $P<0.05$ is considered statistically significant.

NS; not significant.

and tumor suppressors or by acting as oncogenes and tumor suppressors themselves [5]. Furthermore, certain miR-NAs (epi-miR-NAs) counteract $\mathrm{CpG}$ methylation and regulate the components of epigenetic machinery, thus creating a tightly controlled feedback mechanism [5]. MiRNA signatures have been identified in NSCLC, not only demonstrating their biological role but also suggesting them as potential non-invasive diagnostic and therapeutic biomarkers in this type of lung malignancy [6].

Merkel cell polyoma virus (MCPyV) is a double stranded DNA virus that belongs to the family of human polyoma viruses. Several members of the human polyoma viruses have demonstrated oncogenic properties in cell culture and animal models however to date $\mathrm{MCPyV}$ is the only member associated with cancer in humans [7]. The prevalence of MCPyV in Merkel cell carcinomas (MCC) of the skin reaches 80\%[7] while we and others have previously demonstrated the presence of MCPyV in patients with non-small cell lung cancer (NSCLC) [8]. We have shown that the deregulation of Braf and $B c l-2$ is associated with the presence of MCPyV DNA in NSCLC patients, implicating apoptotic pathways with polyoma virus infection in human lung cancer [9]. Although additional studies are needed for the accurate determination of the prevalence of MCPyV in NSCLC, it appears that the presence of this virus may be implicated with carcinogenic phenomena not only in the skin but also in malignancies of the lung [10].

Viruses are known to alter the expression of several host miRNAs in order to highjack cellular machinery for their propagation or to evade antiviral responses while several miRNAs associated with cancer, are also affected by viruses that cause tumours in humans [11]. Information regarding the effect of MCPyV infection on host miRNA expression is extremely limited [12].
Interestingly, $\mathrm{MCPyV}$ appears to suppress the expression of miR-203 though yet unknown mechanisms in MCPyVpositive MCC and this was directly linked to increased cell proliferation and evasion of cell cycle arrest [12].

Considering the emerging interactions between microRNA regulation and MCPyV infection in MCC, we hypothesised that the expression of NSCLC-associated microRNAs may be influenced by the presence of MCPyV in cancerous lung tissues. Thus, in this study, we investigated the expression profiles of the microRNAs previously associated with NSCLC such as miR-21, miR-367, miR155, miR-146a, miR-302c, miR-145 and miR-376c and their corresponding target genes and associated pathways in samples from primary NSCLC that were positive or negative for MCPyV DNA. Our results demonstrated aberrant expression patterns of a miR-21, miR-376c and miR-145 which correlated with the deregulated expression of several target genes, providing novel evidence of a $\mathrm{MCPyV}$ induced epigenetic mechanism in NSCLC.

\section{RESULTS}

\section{Polyomavirus detection}

Initially we tested the NSCLC tissue samples for the presence of MCPyV DNA. Eight $(\mathrm{N}=8)$ NSCLC samples and five of the non-malignant corresponding controls $(\mathrm{N}=5)$ tested positive for MCPyV DNA. Sixteen $(\mathrm{N}=16)$ NSCLC samples and five of the non-malignant corresponding controls $(\mathrm{N}=5)$ tested negative for $\mathrm{MCPyV}$ genomes. From our original cohort [8] we were able to obtain non-malignant appropriate control tissues from 5 NSCLC patients positive for MCPyV and from 5 NSCLC patients negative for MCPyV. Demographics, biopsy results and malignant subtypes of NSCLC of patients are 
Table 2: Expression profiles of microRNAs in lung tissue samples of NSCLC patients and controls in relation to the presence or absence of $\mathrm{MCPyV}$

\begin{tabular}{lccccc}
\hline MEAN \pm SD & $\begin{array}{c}\text { MCPyV +ve } \\
\text { controls }\end{array}$ & $\begin{array}{c}\text { MCPyV +ve } \\
\text { samples }\end{array}$ & $\begin{array}{c}\text { MCPyV -ve } \\
\text { controls }\end{array}$ & \multicolumn{2}{c}{$\begin{array}{c}\text { MCPyV -ve } \\
\text { samples }\end{array}$} \\
\hline miR-21 & $0.43 \pm 0.24$ & $1.13 \pm 0.08$ & $0.49 \pm 0.60$ & $0.88 \pm 0.05$ & 0.013 \\
miR-376c & $2.75 \pm 0.26$ & $6.53 \pm 0.38$ & $2.85 \pm 1.47$ & $5.29 \pm 2.51$ & 0.048 \\
miR-145 & $1.71 \pm 0.23$ & $1.35 \pm 0.21$ & $1.28 \pm 0.43$ & $6.99 \pm 3.99$ & 0.0002 \\
\hline
\end{tabular}

Values are expressed as means $\pm \mathrm{SD}$ (standard deviation).

$P<0.05$ is considered statistically significant.

NS; not significant.

shown in Table 1. The two groups of MCPyV-positive and -negative NSCLC samples were matched for age, gender, smoking history and NSCLC subtypes since no significant differences were observed between the two groups.

The histological types consisted mainly of adenocarcinomas and squamous cell carcinomas. The two predominant histological MCPyV-positive types showed similarities in mean age of the patients.

\section{microRNA expression}

Next, we compared the expression of the microRNAs miR-21, miR-145, miR-146a, miR-155, miR-302c, miR-367 and miR-376c in the MCPyV+ve and MCPyV-ve NSCLC samples and their corresponding control samples. MiR-367, member of a cluster that reprograms fibroblasts to induced pluripotent stem cells [13], and miR-145, a hypothesized tumor suppressor [14], have been shown to be associated with an unfavourable prognosis in resected NSCLC [15], while miR-145 and miR-146a, a mediator of inflammation [16], have been proposed as serum diagnostic biomarkers in NSCLC [17]. MiR-155, a multifunctional microRNA involved in haematopoietic lineage differentiation, immunity and viral infections, inflammation, cancer, and cardiovascular diseases [18], has been hypothesized to induce the development of NSCLC in patients from Asia and America [19]. Mir-376c suppresses non-small-cell lung cancer cell growth and invasion by targeting LRH-1mediated Wnt signaling pathway [20]. MiR-302c has been proposed to prevent Ras-induced senescence by inhibiting p21 [21], while miR-21, the most upregulated microRNA in solid tumours, has been shown to be associated with NSCLC prognosis [22], predict recurrence and unfavourable survival in NSCLC [23] and sensitivity to ionizing radiation [24]. Normalisation was performed using miR-191 as it was found to be the most stably expressed microRNA in FFPE lung samples, as previously suggested [15].

MiR-21 and miR-376c were significantly overexpressed in the NSCLC samples compared to the controls (Table 2, Figure 1). MiR-21 and miR-376c were also significantly higher in MCPyV-positive NSCLC

samples as compared to MCPyV-negative samples (Table 2, Figure 1). Alternatively, miR-145 was significantly overexpressed in MCPyV-negative NSCLC samples compared to MCPyV-positive NSCLC samples and the control non-malignant tissue samples (Figure 1). The expression of miR-367, miR-155, miR-146a and miR$302 \mathrm{c}$ showed no difference either between the MCPyVpositive and the MCPyV-negative NSCLC samples or NSCLC and control samples.

No significant associations were found between gene expression and age, gender, smoking history or NSCLC subtype. The survival curve of both groups did not differ significantly.

\section{Gene expression}

We further sought to investigate the expression profiles of genes targeted by the dysregulated microRNAs in this cohort.

MiR-21 target genes were categorised, mainly based on the hallmarks of cancer [25], a wheel of potential genes targeted by miR-21 in a tumorous environment as well as the potential pathways influenced by miR- 21 . The Pten and Braf genes, involved in the sustenance of proliferative signalling, were significantly underexpressed and overexpressed, respectively in the MCPyV-positive NSCLC samples compared to their corresponding controls (Table 3, Figure 2A). Bcl-2 and Bax, anti- and pro-apoptotic genes, respectively, implicated in resistance to cell death, were underexpressed in the MCPyV-positive NSCLC samples compared to the MCPyV-negative NSCLC samples as well as to the controls (Figure 2B). Genes implicated in the deregulation of genomic stability, p53 and Akt2, were underexpressed in the MCPyV-positive NSCLC samples compared to controls and the MCPyVnegative NSCLC samples (Figure 2C), while Akt1 was underexpressed in the MCPyV-positive NSCLC samples compared to the controls but overexpressed compared to the MCPyV-negative NSCLC samples.

Overexpression was detected for the hypoxiaassociated and innate immune response-inducible transcription factor Hifla in the MCPyV-positive NSCLC samples compared to the controls and the MCPyV- 
negative NSCLC samples (Figure 3A), while the tumorpromoting inflammatory gene Daxx was overexpressed in the MCPyV-positive NSCLC samples compared to the controls as well as the MCPyV-negative NSCLC samples (Figure 3B). Angiogenic deregulator Timp3 was underexpressed in the MCPyV-positive NSCLC samples compared to the controls but overexpressed compared to the MCPyV-negative NSCLC samples (Table 3, Figure 3A). Lastly, $P k r$, an antiviral innate immune response-inducible gene also involved in tumor-promoting inflammatory pathways, was expressed at significantly higher levels in the MCPyV-positive tissue samples compared to the MCPyV-negative tissues (Table 3, Figure 3B). Interestingly, the expression of $P k r$ was significantly suppressed in the malignant tissues.

All miR-21 direct target genes showed a significant negative correlation with miR-21 expression in the MCPyV-positive NSCLC group, apart from Daxx which showed a positive correlation (Table 4). Pten, Bcl-2 and $P k r$ showed moderate negative correlation with miR21 expression in MCPyV-positive NSCLC, while Daxx and Timp3 showed a weaker correlation with miR-21 expression in MCPyV positive NSCLC.

The transcript levels of genes targeted by miR-376c, Alk-7, Mmp9 and Grb2 were significantly decreased in the MCPyV-positive NSCLC samples compared to the controls and MCPyV-negative samples (Table 3, Figure 4). Alk7 and Grb2 strongly negatively correlated with miR367c in the MCPyV-positive NSCLC group (Table 4), while $M m p 9$ showed a weak negative correlation with miR-376c expression in MCPyV-positive NSCLC.

MiR-145 targets genes Oct4, Sox2 and Fascin1 were overexpressed in the MCPyV-positive NSCLC samples compared to the controls and the MCPyV-negative samples (Table 3, Figure 5). Oct4, Sox2 and Fascin1 negatively correlated with miR-145 in the MCPyVpositive NSCLC group (Table 4), Oct4 and Sox2 had a weak correlation result, while Fascin 1 showed a moderate to strong correlation coefficient.

The Akt-1 transcript levels correlated significantly with the smoking status only in the MCPyV-negative group. No other significant correlation between microRNA target gene expression and clinical parameters arose.

\section{DISCUSSION}

The present study aimed to investigate the potential association between human polyomavirus infection and epigenetic alterations involving the expression of microRNAs in NSCLC. Among the evaluated microRNAs, miR-21 and miR-376c showed a modest but significant increased expression in MCPyV-positive NSCLC samples relative to the $\mathrm{MCPyV}$-negative tumour samples. Conversely, miR-145 was strongly downregulated in the MCPyV-positive NSCLC samples relative to the MCPyVnegative tumour samples.

\section{Tumour aggressiveness}

Several miR-21 target genes and associated pathways are implicated in the majority of the hallmarks of cancer [25]. In both MCPyV-positive and MCPyVnegative NSCLC samples, we found high miR-21 levels that were correlated with low PTEN mRNA levels. This inverse association was stronger in the MCPyV-positive tumour samples and may indicate a poor Tyrosine Kinase Inhibitor (TKI) resistance clinical response and a shorter survival [26]. This should be taken into consideration, in combination with data suggesting that the downregulation
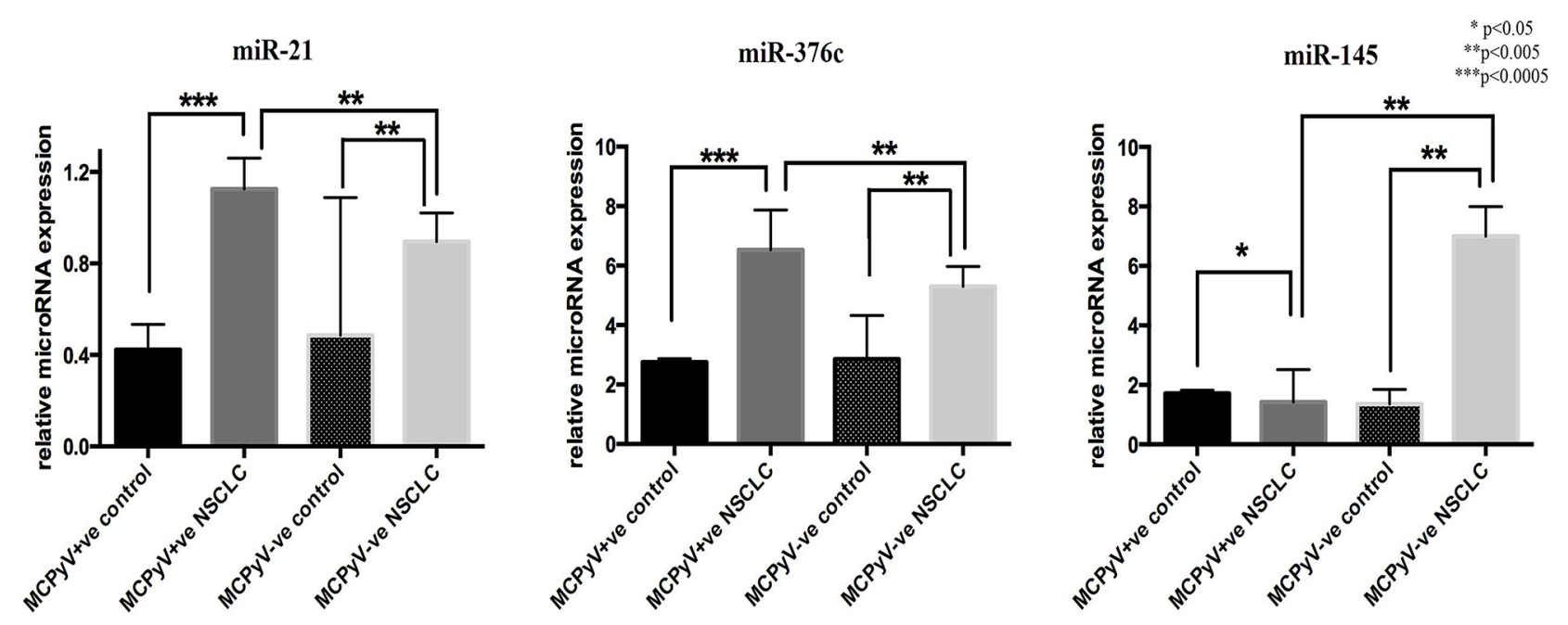

Figure 1: Expression profile of microRNAs in lung tissue samples of NSCLC patients (MCPyV+ve N=8, MCPyV-ve $\mathrm{N}=16$ ) and controls ( $M C P y V+v e ~ N=5, M C P y V-v e ~ N=5)$ in relation to the presence or absence of MCPyV. Samples showed normal distribution, One-way Anova and confirmatory student's t test were used for the analysis. ${ }^{*} \mathrm{p}<0.05,{ }^{* * *} \mathrm{p}<0.005$, ${ }^{* * *} \mathrm{p}<0.0005$. 
Table 3: Expression profiles of microRNAs' target genes in lung tissue samples of NSCLC patients and controls in relation to the presence or absence of $\mathrm{MCPyV}$

\begin{tabular}{|c|c|c|c|c|}
\hline \multicolumn{5}{|c|}{ Gene expression profiles } \\
\hline $\operatorname{MEAN} \pm$ SD & $\begin{array}{c}\text { MCPyV +ve } \\
\text { controls }\end{array}$ & $\begin{array}{c}\text { MCPyV +ve NSCLC } \\
\text { samples }\end{array}$ & $\begin{array}{c}\text { MCPyV-ve } \\
\text { controls }\end{array}$ & $\begin{array}{c}\text { MCPyV -ve NSCLC } \\
\text { samples }\end{array}$ \\
\hline \multicolumn{5}{|c|}{ miR--21 targets } \\
\hline \multicolumn{5}{|c|}{ Direct target genes } \\
\hline Pten & $8.10 \pm 0.8$ & $1.4 \pm 0.02$ & $0.98 \pm 0.32$ & $0.10 \pm 0.00$ \\
\hline$B c l-2$ & $38.30 \pm 5.8$ & $13.40 \pm 2.10$ & $12.32 \pm 9.87$ & $40.90 \pm 6.10$ \\
\hline $\operatorname{Daxx}$ & $10.08 \pm 1.23$ & $16.79 \pm 8.10$ & $8.69 \pm 3.63$ & $7.10 \pm 0.81$ \\
\hline$P k r$ & $357.1 \pm 56.04$ & $64.71 \pm 11.37$ & $41.97 \pm 6.54$ & $46.71 \pm 23.71$ \\
\hline Timp3 & $6.10 \pm 1.31$ & $1.4 \pm 0.02$ & $0.03 \pm 0.00$ & $0.30 \pm 0.00$ \\
\hline \multicolumn{5}{|c|}{ Associated pathways' genes } \\
\hline Braf & $0.53 \pm 0.02$ & $1.60 \pm 0.40$ & $1.03 \pm 0.94$ & $0.10 \pm 0.00$ \\
\hline Bax & $9.50 \pm 1.20$ & $2.4 \pm 0.31$ & $13.69 \pm 4.12$ & $39.1 \pm 3.72$ \\
\hline$p 53$ & $7.60 \pm 2.10$ & $1.90 \pm 0.51$ & $1.56 \pm 0.65$ & $3.6 \pm 0.89$ \\
\hline Akt-1 & $14.50 \pm 1.63$ & $5.30 \pm 0.85$ & $0.03 \pm 0.00$ & $0.4 \pm 0.09$ \\
\hline Akt-2 & $18.10 \pm 3.12$ & $3.10 \pm 1.56$ & $26.45 \pm 13.58$ & $76.5 \pm 9.54$ \\
\hline Hifla & $11.71 \pm 0.98$ & $78.80 \pm 6.57$ & $6.91 \pm 2.23$ & $3.90 \pm 0.09$ \\
\hline \multicolumn{5}{|c|}{ miR--376c targets } \\
\hline Alk7 & $1.13 \pm 0.76$ & $0.22 \pm 0.32$ & $0.58 \pm 1.21$ & $0.62 \pm 0.06$ \\
\hline Mmp9 & $357.1 \pm 56.04$ & $64.71 \pm 11.37$ & $123.89 \pm 55.63$ & $166.71 \pm 15.71$ \\
\hline Grb2 & $12.31 \pm 0.32$ & $1.98 \pm 0.02$ & $5.32 \pm 1.29$ & $6.32 \pm 0.34$ \\
\hline \multicolumn{5}{|c|}{ miR--145 targets } \\
\hline Oct4 & $0.87 \pm 0.02$ & $1.10 \pm 0.41$ & $0.49 \pm 0.02$ & $0.54 \pm 0.26$ \\
\hline Sox 2 & $0.92 \pm 0.38$ & $5.21 \pm 2.78$ & $2.65 \pm 0.03$ & $1.21 \pm 0.72$ \\
\hline Fascin1 & - & $53.16 \pm 12.28$ & - & $28.04 \pm 6.89$ \\
\hline
\end{tabular}

Values are expressed as means $\pm \mathrm{SD}$ (standard deviation).

NS: non significant.

of miRNA-21 could sensitize radioresistant NSCLC cells by inhibiting cell proliferation and enhancing apoptosis through the inhibition of the PI3K/Akt signalling pathway [24]. Braf gene involved in sustaining pro-proliferative signalling was found strongly upregulated in the MCPyVpositive NSCLC samples relative to the MCPyV-negative tumour samples as previously shown [8]. The combination of low Pten levels with high Braf expression provides evidence for increased tumour aggressiveness associated with MCPyV in NSCLC.

We also investigated the $\mathrm{Bax} / \mathrm{Bcl}-2$ equilibrium, which is related to apoptosis resistance in association with miR-21 expression, following up on our previous study [8]. Bax, widely described as a pro-apoptotic factor, and $B c l-2$, representative of anti-apoptotic proteins, were found underexpressed in MCPyV-positive NSCLC cases,

both negatively correlating with miR-21. A ratio of Bax/ $B c l-2$ lower than 1, as was observed in the MCPyVpositive samples, indicates hyperexpression of $B c l-2$ and loss of Bax and has been shown to positively correlate with the severity of the preneoplastic lesions, from lowgrade to high-grade [27].

Importantly MCPyV-positive NSCLC samples showed decreased $p 53$ expression relative to the MCPyVnegative tumour samples. Inhibition of $p 53$ activity is a characteristic of polyoma viruses including MCPyV [28]. Recent data suggest that the inhibition of miR-21 would be beneficial in apoptosis-inducing cancer therapies directed against p53-deficient tumours [29].

It has been suggested that loss of angiogenic deregulator, promotes tumor malignancy and subsequent relapse and poor survival in patients with HPV-infected 
non-small cell lung cancer [30]. In the present study, MCPyV-infected NSCLC cells showed a significant underexpression of Timp 3 compared to the controls. Taken together, these results may hint at a poorer outcome in the presence of MCPyV DNA in NSCLC patients.

MiR-376c, was significantly overexpressed in MCPyV-positive NSCLC samples, and negatively correlated with its target genes, Alk7, Mmp9 and Grb2, in MCPyV-positive NSCLC samples. MiR-376c has been suggested to inhibit Alk7 expression, cell proliferation and apoptosis only in ovarian cancer cell lines [31], and lead to poor chemotherapy response. $M m p 9$, known to promote lung tumour metastasis [32], has been suggested to be inhibited by miR-129 [33] and has been proposed as
A.

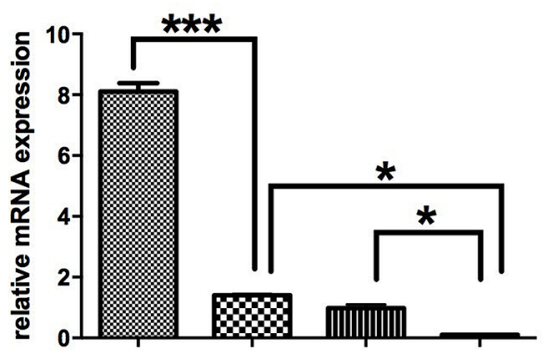

Braf

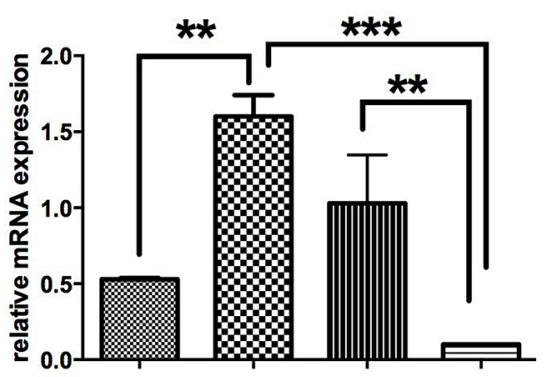

Bax

B.

Bcl-2

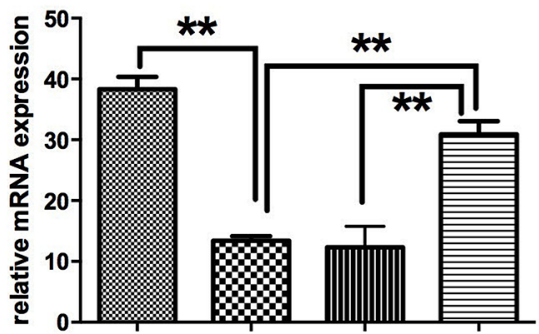

C.

$p 53$

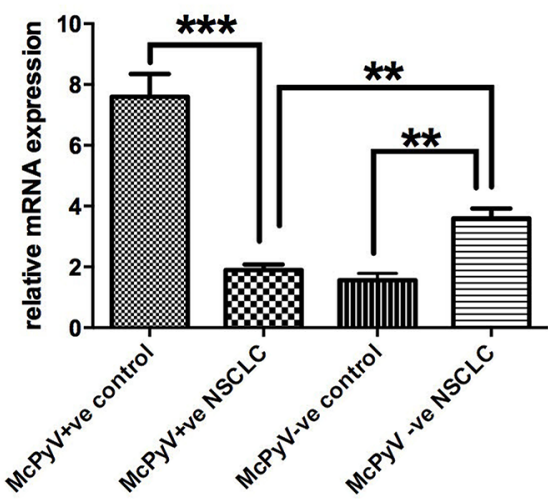

***

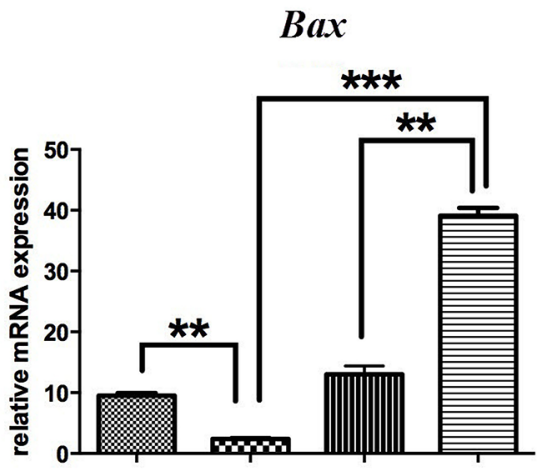

$$
\begin{gathered}
* p<0.05 \\
* * p<0.005 \\
* * * p<0.0005
\end{gathered}
$$

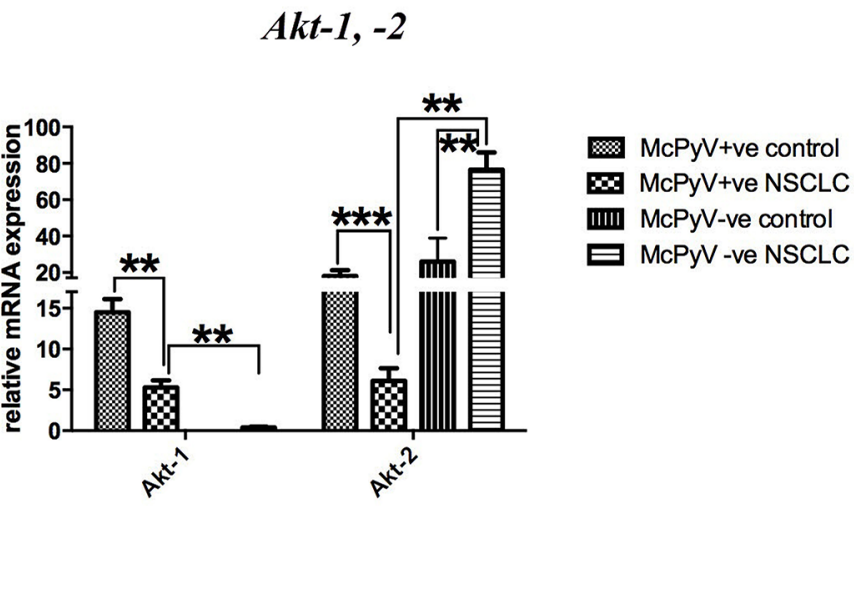

Figure 2: Expression profile of miR-21 target genes and associated pathways' genes Pten, Braf, Bcl-2, Bax, p53, Akt-1, Akt-2 in lung tissue samples of $\mathrm{NSCLC}$ patients $(\mathrm{MCPyV}+\mathrm{ve} \mathrm{N}=\mathbf{8}, \mathrm{MCPyV}-\mathrm{ve} \mathrm{N}=16)$ and controls $(\mathrm{MCPyV}+\mathrm{ve} \mathrm{N}=5$, MCPyV-ve $\mathbf{N}=5$ ) in relation to the presence or absence of MCPyV. Samples showed normal distribution, One-way Anova and confirmatory student's $t$ test were used for the analysis. ${ }^{*} \mathrm{p}<0.05,{ }^{* *} \mathrm{p}<0.005,{ }^{* * *} \mathrm{p}<0.0005$. 
a possible therapeutic target [33]. In addition, cytosolic adaptor protein GRB2, a critical mediator of oncogenic EGFR signaling through activation of RAS [34], is required for survival of cells with mutant EGFR [35]. To the best of our knowledge, this is the first report of $M m p 9$ miR-376c mediated inhibition in human NSCLC, as well as miR-376c mediated Grb2 downregulation in MCPyVpositive tumour samples.

Importantly, miR-145, a suggested tumor-suppressor [36] was strongly downregulated in MCPyV-positive

A.

Hif1a

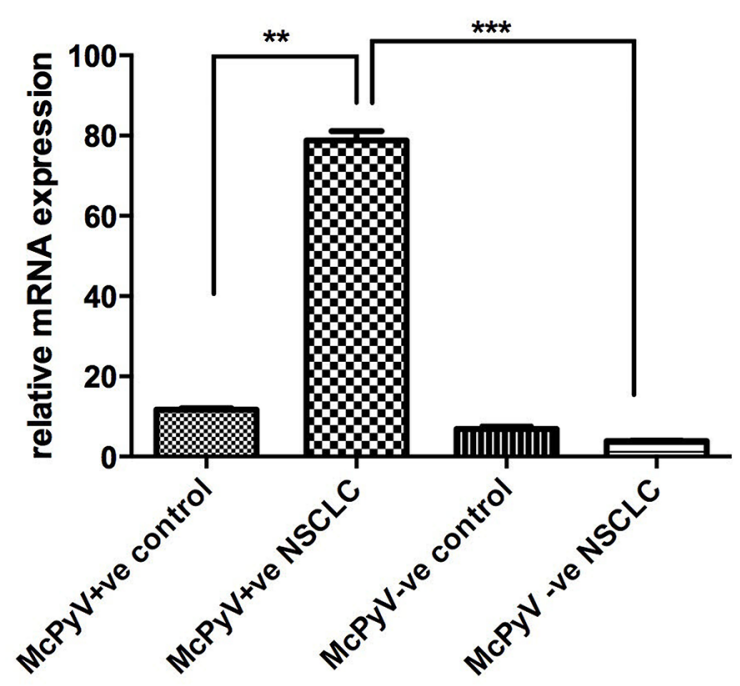

B.

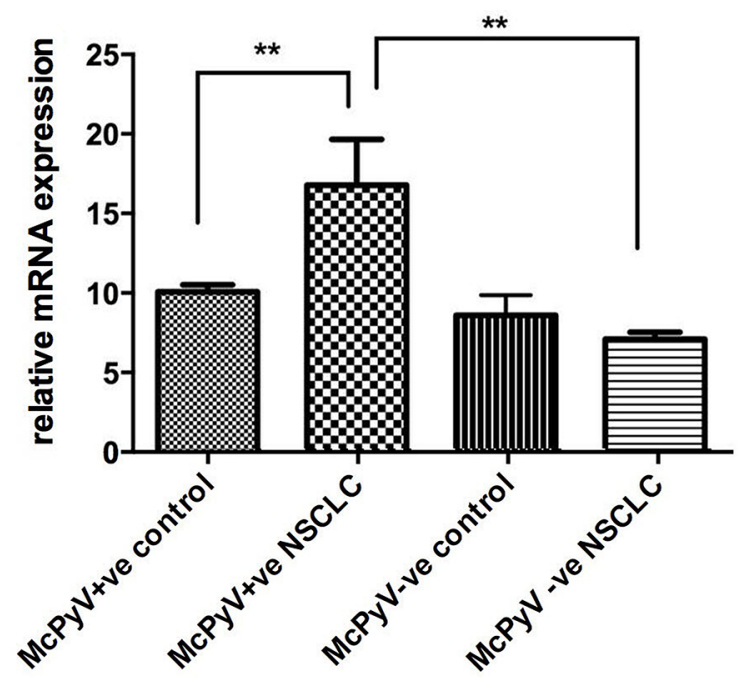

NSCLC compared to MCPyV-negative NSCLC, while it was significantly higher in MCPyV-negative NSCLC relative to the non-malignant controls. This striking difference was also reflected in the miR-145 target genes, Oct4/Sox $2 /$ Fascin 1 which were all upregulated in the MCPyV-positive tumour samples. It has been shown that miR-145 expression is negatively correlated with the levels of Oct4/Sox2/Fascin1 in lung adenocarcinoma and an Oct4(high)/Sox2(high)/Fascin1(high)/miR145(low) phenotype, as in the present study, predicted poor
Timp3
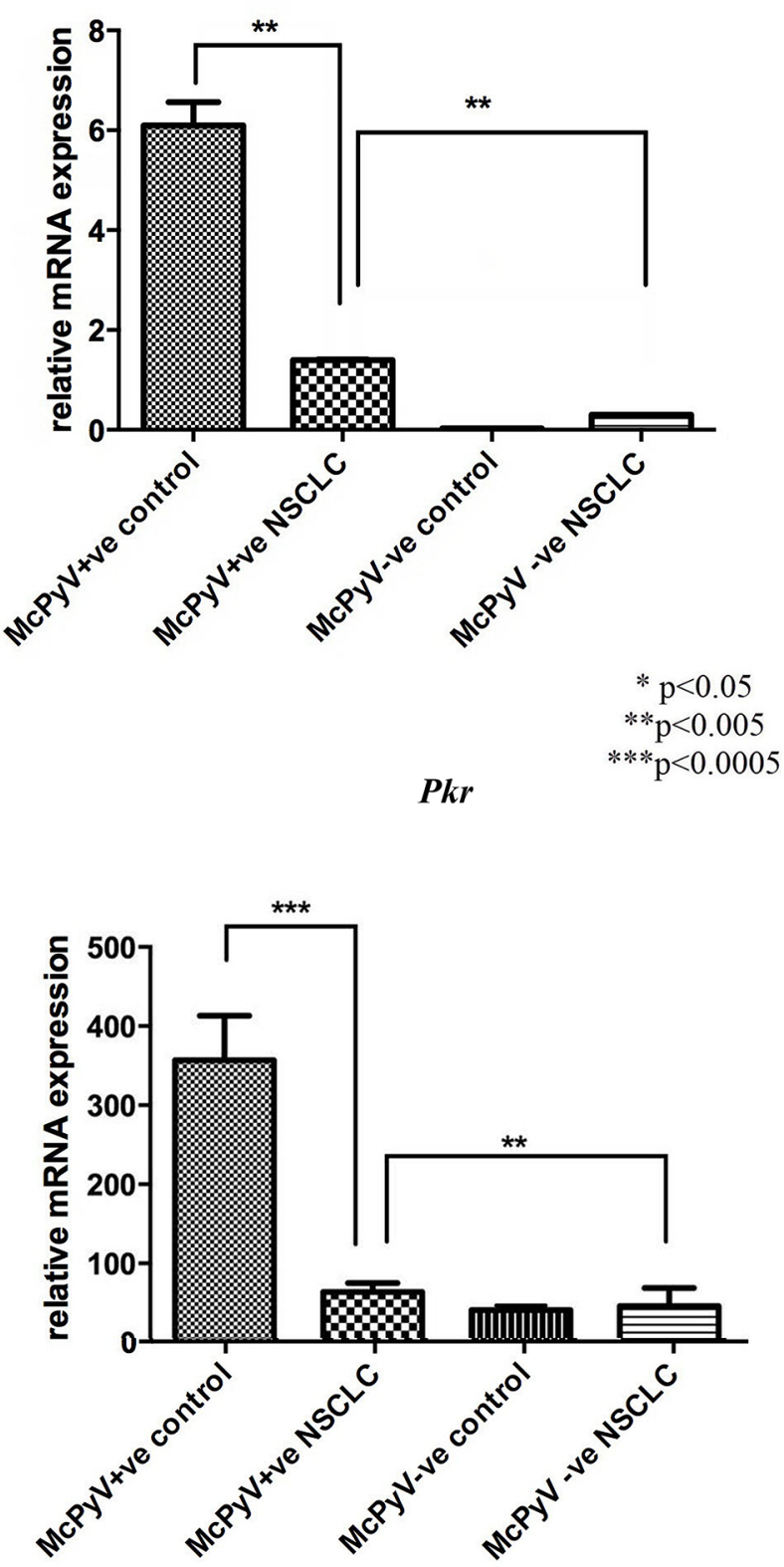

Figure 3: Expression profile of miR-21 target genes and associated pathways' genes Hif1a, Timp3, Daxx, Pkr in lung tissue samples of NSCLC patients $(\mathrm{MCPyV}+\mathrm{ve} \mathrm{N}=\mathbf{8}, \mathrm{MCPyV}$-ve $\mathrm{N}=16)$ and controls $(\mathrm{MCPyV}+\mathrm{ve} \mathrm{N}=5, \mathrm{MCPyV}-\mathrm{ve}$ $\mathbf{N}=5$ ) in relation to the presence or absence of MCPyV. Samples showed normal distribution, One-way Anova and confirmatory student's t test were used for the analysis. ${ }^{*} \mathrm{p}<0.05,{ }^{* *} \mathrm{p}<0.005,{ }^{* * *} \mathrm{p}<0.0005$. 
Table 4: Correlations between microRNAs and their target genes in lung tissue samples of NSCLC patients and controls in relation to the presence or absence of MCPyV

\begin{tabular}{|c|c|c|c|c|}
\hline \multicolumn{5}{|c|}{ Correlations } \\
\hline $\mathbf{r} / \mathbf{r}^{2} / \mathbf{p}$ value & MCPyV +ve controls & $\begin{array}{c}\text { MCPyV +ve NSCLC } \\
\text { samples }\end{array}$ & MCPyV -ve controls & $\begin{array}{c}\text { MCPyV -ve NSCLC } \\
\text { samples }\end{array}$ \\
\hline \multicolumn{5}{|c|}{ Correlation of target genes with miR--21 } \\
\hline Pten & NS & $\begin{array}{c}r=-0.6205, r^{2}=0.3850 \\
p=0.0009\end{array}$ & NS & $\begin{array}{c}r=-0.4027, r^{2}=0.1621 \\
p=0.0460\end{array}$ \\
\hline Bcl-2 & $\begin{array}{c}r=+0.5603, r^{2}=0.3139 \\
p=0.0036\end{array}$ & $\begin{array}{c}\mathrm{r}=-0.5044, \mathrm{r}^{2}=0.2544 \\
\mathrm{p}=0.0101\end{array}$ & NS & NS \\
\hline $\operatorname{Daxx}$ & NS & $\begin{array}{c}\mathrm{r}=+0.4309, \mathrm{r}^{2}=0.1857 \\
\mathrm{p}=0.0315\end{array}$ & NS & $\begin{array}{c}r=-0.2398, r^{2}=0.2598 \\
p=0.0047\end{array}$ \\
\hline Timp3 & NS & $\begin{array}{c}\mathrm{r}=-0.4293, \mathrm{r}^{2}=0.1843 \\
\mathrm{p}=0.0322\end{array}$ & $\begin{array}{c}r=-0.8293, r^{2}=0.5845 \\
p=0.0432\end{array}$ & $\begin{array}{c}r=-0.1493, r^{2}=0.3649 \\
p=0.0212\end{array}$ \\
\hline$P k r$ & NS & $\begin{array}{c}r=-0.4946, r^{2}=0.2446 \\
p=0.0266\end{array}$ & NS & $\begin{array}{c}r=-0.9746, r^{2}=0.6597 \\
p=0.0023\end{array}$ \\
\hline \multicolumn{5}{|c|}{ Correlation of target genes with miR--376c } \\
\hline Alk7 & NS & $\begin{array}{c}\mathrm{r}=-0.6951, \mathrm{r}^{2}=0.5912 \\
\mathrm{p}=0.0251\end{array}$ & NS & NS \\
\hline Mmp9 & $\begin{array}{c}\mathrm{r}=+0.4351, \mathrm{r}^{2}=0.1964 \\
\mathrm{p}=0.0387\end{array}$ & $\begin{array}{c}\mathrm{r}=-0.3416, \mathrm{r}^{2}=0.4108 \\
\mathrm{p}=0.0023\end{array}$ & NS & $\begin{array}{c}r=+0.6941, r^{2}=0.4679 \\
p=0.0039\end{array}$ \\
\hline Grb2 & $\begin{array}{c}\mathrm{r}=+0.6398, \mathrm{r}^{2}=0.2415 \\
\mathrm{p}=0.0289\end{array}$ & $\begin{array}{c}r=-0.7589, r^{2}=0.6341 \\
p=0.0049\end{array}$ & NS & NS \\
\hline \multicolumn{5}{|c|}{ Correlation of target genes with miR--145 } \\
\hline Oct 4 & NS & $\begin{array}{c}\mathrm{r}=+0.2341, \mathrm{r}^{2}=0.3019 \\
\mathrm{p}=0.0056\end{array}$ & $\begin{array}{c}\mathrm{r}=+0.1956, \mathrm{r}^{2}=0.2098 \\
\mathrm{p}=0.0042\end{array}$ & $\begin{array}{c}r=-0.6832, r^{2}=0.5912 \\
p=0.0183\end{array}$ \\
\hline Sox 2 & NS & $\begin{array}{c}\mathrm{r}=+0.3965, \mathrm{r}^{2}=0.4170 \\
\mathrm{p}=0.0038\end{array}$ & NS & $\begin{array}{c}r=-0.9230, r^{2}=0.7154 \\
p=0.0058\end{array}$ \\
\hline Fascin1 & - & $\begin{array}{c}\mathrm{r}=+0.6231, \mathrm{r}^{2}=0.5439 \\
\mathrm{p}=0.0008\end{array}$ & - & $\begin{array}{c}r=-0.2206, r^{2}=0.1905 \\
p=0.0029\end{array}$ \\
\hline
\end{tabular}

NS: non significant, $r=$ Pearson's $r$ coefficient, $\mathrm{r}^{2}=$ coefficient of determination.

Alk7
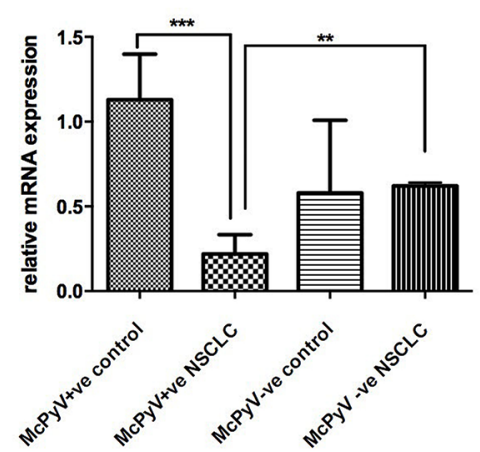

Mmp9
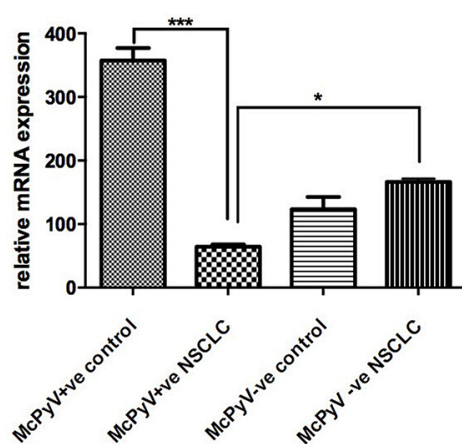

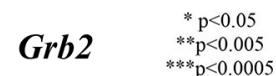

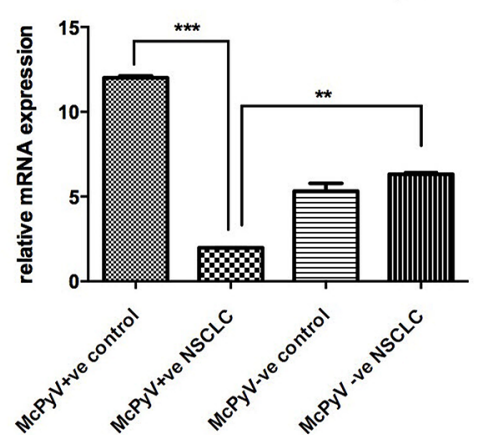

Figure 4: Expression profile of miR-376c target genes $A l k 7, M m p 9$, Grb2 in lung tissue samples of NSCLC patients $(\mathrm{MCPyV}+\mathrm{ve} \mathrm{N}=8, \mathrm{MCPyV}$-ve $\mathrm{N}=16)$ and controls $(\mathrm{MCPyV}+\mathrm{ve} \mathrm{N}=5, \mathrm{MCPyV}$-ve $\mathrm{N}=5)$ in relation to the presence or absence of MCPyV. Samples showed normal distribution, One-way Anova and confirmatory student's test were used for the analysis. ${ }^{*} \mathrm{p}<0.05,{ }^{* *} \mathrm{p}<0.005,{ }^{* * *} \mathrm{p}<0.0005$. 
Table 5: Primer sequences used for quantitative Real-Time RT-PCR

\begin{tabular}{|c|c|c|}
\hline Gene & Primer pair sequence (5'-3') & $\begin{array}{l}\text { Annealing } \\
\text { temperature }\end{array}$ \\
\hline GAPDH & $\begin{array}{l}\text { FOR: AGCCACATCGCTCAGACAC } \\
\text { REV : GCCCAATACGACCAAATCC }\end{array}$ & $54{ }^{\circ} \mathrm{C}$ \\
\hline Braf & $\begin{array}{l}\text { FOR: AGAAAGCACTGATGATGAGAGG } \\
\text { REV: GGAAATATCAGTGTCCCAACCA }\end{array}$ & $58^{\circ} \mathrm{C}$ \\
\hline $\mathrm{Bcl}-2$ & $\begin{array}{l}\text { FOR: GAAACCCCTAGTGCCATCAA } \\
\text { REV: GGGACGTCAGGTCACTGAAT }\end{array}$ & $55^{\circ} \mathrm{C}$ \\
\hline$p 53$ & $\begin{array}{l}\text { FOR: GTGAGCGCTTCGAGATGTTC } \\
\text { REV: ATGGCGGGAGGTAGACTGAC }\end{array}$ & $60^{\circ} \mathrm{C}$ \\
\hline Akt-1 & $\begin{array}{l}\text { FOR: GCAGCACGTGTACGAGAAGA } \\
\text { REV: GGTGTCAGTCTCCGACGTG }\end{array}$ & $54{ }^{\circ} \mathrm{C}$ \\
\hline Akt-2 & $\begin{array}{l}\text { FOR: CTCACACAGTCACCGAGAGC } \\
\text { REV: TGGGTCTGGAAGGCATACTT }\end{array}$ & $56^{\circ} \mathrm{C}$ \\
\hline $\operatorname{Bax}$ & $\begin{array}{l}\text { FOR: TTCTGACGGCAACTTCAACTG } \\
\text { REV: TTGGTGCACAGGGCCTGTAATC }\end{array}$ & $61{ }^{\circ} \mathrm{C}$ \\
\hline $\operatorname{Daxx}$ & $\begin{array}{l}\text { FOR: CATGCGAGGTTCTGAGAATTG } \\
\text { REV:GAGGAAGTGGTGGGGATTTC }\end{array}$ & $54{ }^{\circ} \mathrm{C}$ \\
\hline Pten & $\begin{array}{l}\text { FOR:CGGCAGCATCAAATGTTTCAG } \\
\text { REV:CGGCAGCATCAAATGTTTCAG }\end{array}$ & $55^{\circ} \mathrm{C}$ \\
\hline
\end{tabular}

prognosis [37]. Moreover, it was also revealed that the repressive effect of miR-145 on tumour metastasis was mediated by inhibiting the epithelial-mesenchymal transdifferentiation (EMT) and metastastic ability, partially by regulating Oct4/Sox $2 /$ Fascin 1 [37].

\section{Innate anti-virus response}

In the present study, miR-21 target genes and associated pathways involved in anti-viral response, type I interferoninducible genes Daxx, Pkr, as well as Hifla, were analysed in NSCLC cases. Daxx and Hifla expression increased in
MCPyV positive NSCLC while it correlated positively with miR-21 expression, suggesting that Daxx expression was not directly regulated by miR-21 in MCPyV positive NSCLC. $P k r$ was upregulated in MCPyV positive non-malignant tissues and not in MCPyV positive NSCLC tissues where it negatively correlated with miR-21 expression. Implication of Daxx and Hifla in DNA hypermethylation and apoptosis [38] has recently emerged, while Hifla overexpression, as in MCPyV-positive NSCLC samples, has been associated [39] with the formation of cancer-stem-like-like cells undergoing a process of endothelial-mesenchymal transition, both of which are inhibited by miR-21. In the present study, Daxx and Hifla
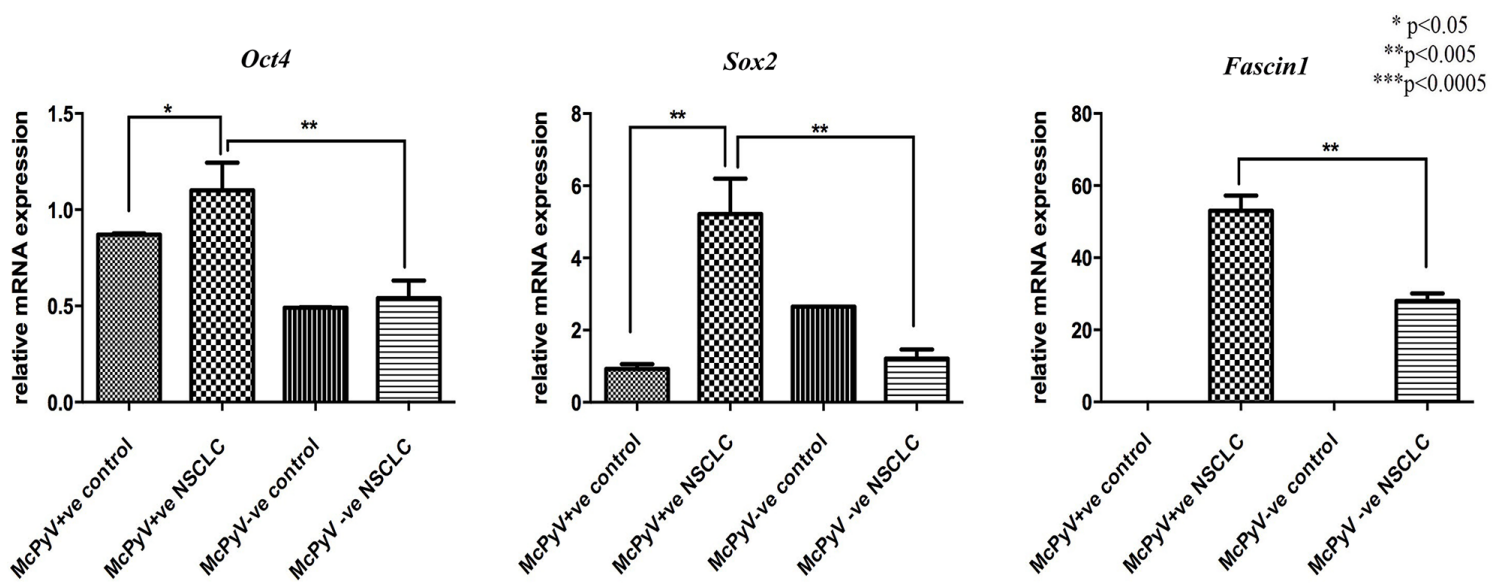

Figure 5: Expression profile of miR-145 target genes Oct4, Sox2, Fascin1 in lung tissue samples of NSCLC patients $(\mathrm{MCPyV}+\mathrm{ve} \mathrm{N}=8, \mathrm{MCPyV}$-ve $\mathrm{N}=16)$ and controls $(\mathrm{MCPyV}+\mathrm{ve} \mathrm{N}=5, \mathrm{MCPyV}$-ve $\mathrm{N}=5)$ in relation to the presence or absence of MCPyV. Samples showed normal distribution, One-way Anova and confirmatory student's t test were used for the analysis. ${ }^{*} \mathrm{p}<0.05,{ }^{* *} \mathrm{p}<0.005,{ }^{* * *} \mathrm{p}<0.0005$. 
Table 5: Primer sequences used for quantitative Real-Time RT-PCR

\begin{tabular}{|c|c|c|}
\hline Gene & Primer pair sequence (5'-3') & $\begin{array}{c}\text { Annealing } \\
\text { temperature }\end{array}$ \\
\hline$P k r$ & $\begin{array}{l}\text { FOR: CCATGGGGAATTACATAGGC } \\
\text { REV: CTTTCTGTCCCATTTTGCATT }\end{array}$ & $52^{\circ} \mathrm{C}$ \\
\hline Hifla & $\begin{array}{l}\text { FOR: CTTGCATGGCTCTCAGATTCAC } \\
\text { REV: AGAGGACAAGCAGATTCAAGGTG }\end{array}$ & $60^{\circ} \mathrm{C}$ \\
\hline Timp3 & $\begin{array}{l}\text { FOR: GGCGGCAGCAGCGGCAATGAC } \\
\text { REV: TACCAGCTTCTTCCCCACCACCTT }\end{array}$ & $60^{\circ} \mathrm{C}$ \\
\hline Grb2 & $\begin{array}{l}\text { FOR: CCATCGCCAAATATGACTTCAAA } \\
\text { REV: CTTCGTTCAAAACCTTGAGGATGT }\end{array}$ & $62^{\circ} \mathrm{C}$ \\
\hline Alk7 & $\begin{array}{l}\text { FOR: ATGACCCGGGCGCTCTGCTCA } \\
\text { REV: ATACTGTCAGCATCGCAGCTA }\end{array}$ & $58^{\circ} \mathrm{C}$ \\
\hline Mmp9 & $\begin{array}{l}\text { FOR: ACTTTGACAGCGACAAGAGGTG } \\
\text { REV: CCGGCACTGAGGAATGATCTAA }\end{array}$ & $64^{\circ} \mathrm{C}$ \\
\hline Oct4 & $\begin{array}{l}\text { FOR: AGGGAAGGAGATTATGGAGGAGG } \\
\text { REV: AGCTTTGGGCTCTGGAAGGC }\end{array}$ & $60^{\circ} \mathrm{C}$ \\
\hline Sox 2 & $\begin{array}{l}\text { FOR: AGGATAAGTACACGCTGCCC } \\
\text { REV: TAACTGTCCATGCGCTGGTT }\end{array}$ & $57^{\circ} \mathrm{C}$ \\
\hline Fascin1 & $\begin{array}{l}\text { FOR: CGCTCCAGCTATGACGTCTTCC } \\
\text { REV: CAGGAGAACCTGCCTTTGATGTT }\end{array}$ & $60^{\circ} \mathrm{C}$ \\
\hline microRNA & microRNA Assay ID & \\
\hline Has-miR--191 & 002299 & $60^{\circ} \mathrm{C}$ \\
\hline Has-miR--21 & 000397 & $60^{\circ} \mathrm{C}$ \\
\hline Has-miR--145 & 000467 & $60^{\circ} \mathrm{C}$ \\
\hline Has-miR--146a & 000468 & $60^{\circ} \mathrm{C}$ \\
\hline Has-miR--155 & 002623 & $60^{\circ} \mathrm{C}$ \\
\hline $\begin{array}{l}\text { hsa-miR--302c- } \\
3 p\end{array}$ & 000533 & $60^{\circ} \mathrm{C}$ \\
\hline Has-miR--367 & 000555 & $60^{\circ} \mathrm{C}$ \\
\hline Has-miR--376c & 002122 & $60^{\circ} \mathrm{C}$ \\
\hline
\end{tabular}

expression correlated positively with miR-21 expression in NSCLC, suggesting a miR-21-independent expression in NSCLC. $P k r$, which negatively correlated with miR-21 overexpression in MCPyV-positive NSCLC specimens, has been suggested to be markedly involved in the development of NSCLC and may serve as a potential prognostic marker for patients with this deadly disease [40]. $P k r$ was upregulated only in non-malignant tissues and not in NSCLC tissues. This may suggest a possible $P k r$ inhibition in tumour cells which would inhibit the arrest in cellular translation processes and subsequently result in both virus and tumour cell resistance to a potent intrinsic cellular defence mechanism.

In conclusion, the present study explored the epigenetic alterations in lung tumor cells caused by the presence of MCPyV DNA in NSCLC patients. The expression profiles of microRNAs and their target genes in this study leads to the hypothesis that the presence of Merkel Cell Polyoma virus may lead to a more aggressive
NSCLC as well as poorer outcomes in NSCLC prognosis. As a single miRNA may inhibit up to several hundred mRNAs, aberrant miRNA expression may suppress a multitude of transcripts and profoundly influence cancerrelated signalling pathways; thus, these results must be interpreted with caution. Further research, particularly on therapeutic interventions is essential in delineating epigenetic mechanisms implicated in this deadly disease.

\section{MATERIALS AND METHODS}

\section{Patients}

The lung tissue patient group comprised of 24 consecutive patients with non-small cell lung cancer (NSCLC) from the Department of Thoracic Medicine, University Hospital of Heraklion, Crete, Greece. The patients included in this study were classified according 
to the criteria of WHO (1997). The tissue control group consisted of 10 samples from macroscopically healthy sites of the lung derived from NSCLC patients included in this cohort and were histologically verified. Demographics and lung carcinoma subtypes of all patients are summarized in Table 1.

\section{Ethics statement}

The Ethics Committee of the University Hospital of Heraklion, Crete approved the protocol (Reg. No 140/42-2015) and all patients and control subjects provided informed consent in written form.

\section{Biological samples and processing}

Twenty-four lung cancer tissue specimens and 10 non-malignant specimens from corresponding patients were obtained from paraffin-embedded blocks from the Laboratory of Pathology, University Hospital of Heraklion, Crete. All the samples were obtained from surgical resections.

\section{MCPyV detection, MicroRNA and mRNA expression}

Twenty four paraffin-embedded tissue specimens from NSCLC patients and ten corresponding controls (from macroscopically and histologically verified healthy sites of respective appropriate controls from 5 NSCLC patients positive for MCPyV and from 5 NSCLC patients negative for MCPyV in this cohort) were processed using RecoverAll ${ }^{\mathrm{TM}}$ Total nucleic acid isolation from Ambion, for the isolation of total RNA as recommended by the manufacturer. RNA concentration and purity were evaluated by a spectrophotometer (Nanodrop).

The presence of MCPyV DNA was tested using RealTime quantitative PCR protocols, using the MCV138 set of primers, which targets the Large T antigen (LTA) region, as previously described [8]. The integrity and quality of the extracted DNA were confirmed after the successful amplification of the beta2-microglobulin gene in all samples.

Particular care was taken and all manipulations were performed inside a PCR-hood to avoid potential contamination. Each PCR reaction contained two negative controls. DNA from a Merkel cell carcinoma patient served as the positive control. All Real-Time PCR reactions were carried out in an Mx3000P Real Time PCR system while additionally, PCR end-products were analyzed on a $2 \%$ agarose gel, stained with ethidium bromide and the bands were visualized under a UV transilluminator $(260 \mathrm{~nm})$. These viral PCR products were then subjected to direct sequencing analysis to verify the specific amplification of the MCPyV LTA region.

For the analysis of microRNA expression levels, 10ng total RNA were used in reverse transcriptase and Real-Time qPCR reactions using the TaqMan ${ }^{\mathrm{TM}}$ microRNA assays (Life Technologies) and 7500 Fast Real-Time PCR system (Applied Biosystems). Reverse transcription was performed at $16^{\circ} \mathrm{C}$ for $15 \mathrm{~min}, 42^{\circ} \mathrm{C}$ for $30 \mathrm{~min}, 85^{\circ} \mathrm{C}$ for 5 min and 2 fold diluted cDNA samples were analysed by Real-Time PCR $\left(95^{\circ} \mathrm{C}\right.$ for $10 \mathrm{~min}$, followed by 40 cycles of $95^{\circ} \mathrm{C}$ for $15 \mathrm{sec}, 60^{\circ} \mathrm{C}$ for $1 \mathrm{~min}$ ). Probe and primer sequences are summarized in Table 5. miR-191 was used as endogenous control for the normalization of microRNA expression levels in all samples, due to its high stability and consistency, as previously described [14, 41].

For gene expression analyses, 500ng of total RNA were first treated with DNAfree (Ambion) in order to remove genomic DNA contamination, followed by $1^{\text {st }}$ strand cDNA synthesis using Maxima RT TM (Fermentas) and Real-Time qPCR analysis using Maxima SYBR-Green qPCRmix (Fermentas) on a Mx3005P qPCR system (Agilent Technologies). RT reaction was performed at $25^{\circ} \mathrm{C}$ for 10 $\min , 50^{\circ} \mathrm{C}$ for $20 \mathrm{~min}, 65^{\circ} \mathrm{C}$ for $10 \mathrm{~min}$ and $85^{\circ} \mathrm{C}$ for $5 \mathrm{~min}$. 6 fold diluted cDNA samples were analysed by Real-Time PCR $\left(95^{\circ} \mathrm{C}\right.$ for $10 \mathrm{~min}$, followed by 40 cycles of $95^{\circ} \mathrm{C}$ for 15 sec, primer pair specific annealing temperature (Table 5$)^{\circ} \mathrm{C}$ for $30 \mathrm{sec}, 72^{\circ} \mathrm{C}$ for $30 \mathrm{sec}$, followed by $72^{\circ} \mathrm{C}$ for $10 \mathrm{~min}$ ). Transcript levels of validated miR-21 target genes (Pten, $\mathrm{Bcl}$ 2, Daxx, Pkr, Timp3, validated miR-376c target genes (Grb2, Alk7, Mmp9) and validated miR-145 target genes (Oct4, Sox2, Fascin1) obtained from TarBase.v7 were evaluated. We also evaluated the following genes associated with target genes and apoptotic pathways of miR-21 p53 [42], Braf [43], Akt-1, Akt-2 [44], BaxX [45], Hifla [46]. GAPDH levels were used as endogenous control for the normalization of mRNA expression levels in all samples. Primers sequences and annealing temperatures are shown in Table 5.

\section{Statistical analysis}

The Kolmogorov-SmiRnov test was used to determine whether the expression data obtained followed a normal distribution pattern. The mRNA expression of all the genes was compared between the groups of normal and pathological samples, as well as between groups with different histological features, using parametric procedures (Student's t-test and One way Anova), as all sample groups followed Gaussian (normal) distribution. Linear regression between microRNAs and their target genes were analysed with the Linear (Pearson) correlation test. Probability values (P-values) $<0.05$ were considered statistically significant. Statistical calculations were performed using SPSS 11.5 software (SPSS, Chicago, IL, USA).

\section{ACKNOWLEDGMENTS}

This work was partly funded by the European Commission FP7 program "Translational Potential" (TransPOT; EC contract number 285948) and the Special Account for Research, University of Crete (KA 2852). The funders had no role in study design, data collection and analysis, decision to publish, or preparation of the manuscript. 


\section{CONFLICTS OF INTEREST}

The authors declare no conflicts of interest.

\section{REFERENCES}

1. Jemal A, Siegel R, Xu J, Ward E. Cancer statistics, 2010. CA Cancer J Clin. 2010; 60:277-300. https://doi. org/10.3322/caac.20073.

2. Forde PM, Brahmer JR, Kelly RJ. New strategies in lung cancer: epigenetic therapy for non-small cell lung cancer. Clin Cancer Res. 2014; 20:2244-48. https://doi. org/10.1158/1078-0432.CCR-13-2088.

3. Yang IV, Schwartz DA. Epigenetic control of gene expression in the lung. Am J Respir Crit Care Med. 2011; 183:1295-301. https://doi.org/10.1164/rccm.201010-1579PP.

4. Joshi P, Middleton J, Jeon YJ, Garofalo M. MicroRNAs in lung cancer. World J Methodol. 2014; 4:59-72. https://doi. org/10.5662/wjm.v4.i2.59.

5. Momi N, Kaur S, Rachagani S, Ganti AK, Batra SK. Smoking and microRNA dysregulation: a cancerous combination. Trends Mol Med. 2014; 20:36-47. https://doi. org/10.1016/j.molmed.2013.10.005.

6. Wang H, Wu S, Zhao L, Zhao J, Liu J, Wang Z. Clinical use of microRNAs as potential non-invasive biomarkers for detecting non-small cell lung cancer: a meta-analysis. Respirology. 2015; 20:56-65. https://doi.org/10.1111/resp.12444.

7. Moens U, Rasheed K, Abdulsalam I, Sveinbjørnsson B. The role of Merkel cell polyomavirus and other human polyomaviruses in emerging hallmarks of cancer. Viruses. 2015; 7:1871-901. https://doi.org/10.3390/v7041871.

8. Lasithiotaki I, Antoniou KM, Derdas SP, Sarchianaki E, Symvoulakis EK, Psaraki A, Spandidos DA, Stathopoulos EN, Siafakas NM, Sourvinos G. The presence of Merkel cell polyomavirus is associated with deregulated expression of BRAF and Bcl-2 genes in non-small cell lung cancer. Int J Cancer. 2013; 133:604-11. https://doi.org/10.1002/ijc.28062.

9. Joh J, Jenson AB, Moore GD, Rezazedeh A, Slone SP, Ghim SJ, Kloecker GH. Human papillomavirus (HPV) and Merkel cell polyomavirus (MCPyV) in non small cell lung cancer. Exp Mol Pathol. 2010; 89:222-26. https://doi. org/10.1016/j.yexmp.2010.08.001.

10. Hashida Y, Imajoh M, Nemoto Y, Kamioka M, Taniguchi A, Taguchi T, Kume M, Orihashi K, Daibata M. Detection of Merkel cell polyomavirus with a tumour-specific signature in non-small cell lung cancer. Br J Cancer. 2013; 108:62937. https://doi.org/10.1038/bjc.2012.567.

11. Guo YE, Steitz JA. Virus meets host microRNA: the destroyer, the booster, the hijacker. Mol Cell Biol. 2014; 34:3780-87. https://doi.org/10.1128/MCB.00871-14.

12. Xie H, Lee L, Caramuta S, Höög A, Browaldh N, Björnhagen V, Larsson C, Lui WO. MicroRNA expression patterns related to merkel cell polyomavirus infection in human merkel cell carcinoma. J Invest Dermatol. 2014; 134:507-17. https://doi.org/10.1038/jid.2013.355.

13. Kaid C, Silva PB, Cortez BA, Rodini CO, Semedo-Kuriki P, Okamoto OK. miR-367 promotes proliferation and stemlike traits in medulloblastoma cells. Cancer Sci. 2015; 106:1188-95. https://doi.org/10.1111/cas.12733.

14. Guo YH, Zhang C, Shi J, Xu MH, Liu F, Yuan HH, Wang JY, Jiang B, Gao FH. Abnormal activation of the EGFR signaling pathway mediates the downregulation of miR-145 through the ERK1/2 in non-small cell lung cancer. Oncol Rep. 2014; 31:1940-46. https://doi.org/10.3892/or.2014.3021.

15. Campayo M, Navarro A, Viñolas N, Diaz T, Tejero R, Gimferrer JM, Molins L, Cabanas ML, Ramirez J, Monzo M, Marrades R. Low miR-145 and high miR-367 are associated with unfavourable prognosis in resected nonsmall cell lung cancer. Eur Respir J. 2013; 41:1172-78. https://doi.org/10.1183/09031936.00048712.

16. Hou ZH, Han QJ, Zhang C, Tian ZG, Zhang J. miR146a impairs the IFN-induced anti-HBV immune response by downregulating STAT1 in hepatocytes. Liver Int. 2014; 34:58-68. https://doi.org/10.1111/liv.12244.

17. Wang RJ, Zheng YH, Wang P, Zhang JZ. Serum miR-125a-5p, miR-145 and miR-146a as diagnostic biomarkers in non-small cell lung cancer. Int J Clin Exp Pathol. 2015; 8:765-71.

18. Faraoni I, Antonetti FR, Cardone J, Bonmassar E. miR-155 gene: a typical multifunctional microRNA. Biochim Biophys Acta. 2009; 1792:497-505. https://doi. org/10.1016/j.bbadis.2009.02.013.

19. Wang F, Zhou J, Zhang Y, Wang Y, Cheng L, Bai Y, Ma H. The Value of MicroRNA-155 as a Prognostic Factor for Survival in Non-Small Cell Lung Cancer: A Meta-Analysis. PLoS One. 2015; 10:e0136889. https://doi.org/10.1371/ journal.pone. 0136889 .

20. Jiang W, Tian Y, Jiang S, Liu S, Zhao X, Tian D. MicroRNA-376c suppresses non-small-cell lung cancer cell growth and invasion by targeting LRH-1-mediated Wnt signaling pathway. Biochem Biophys Res Commun. 2016; 473:980-86. https://doi.org/10.1016/j.bbrc.2016.04.002.

21. Borgdorff V, Lleonart ME, Bishop CL, Fessart D, Bergin $\mathrm{AH}$, Overhoff MG, Beach DH. Multiple microRNAs rescue from Ras-induced senescence by inhibiting p21(Waf1/Cip1). Oncogene. 2010; 29:2262-71. https://doi. org/10.1038/onc.2009.497.

22. Ma XL, Liu L, Liu XX, Li Y, Deng L, Xiao ZL, Liu YT, Shi HS, Wei YQ. Prognostic role of microRNA-21 in non-small cell lung cancer: a meta-analysis. Asian Pac J Cancer Prev. 2012; 13:2329-34. https://doi.org/10.7314/ APJCP.2012.13.5.2329.

23. Yang M, Shen H, Qiu C, Ni Y, Wang L, Dong W, Liao Y, Du J. High expression of miR-21 and miR-155 predicts recurrence and unfavourable survival in non-small cell lung cancer. Eur J Cancer. 2013; 49:604-15. https://doi. org/10.1016/j.ejca.2012.09.031. 
24. Ma Y, Xia H, Liu Y, Li M. Silencing miR-21 sensitizes non-small cell lung cancer A549 cells to ionizing radiation through inhibition of PI3K/Akt. BioMed Res Int. 2014; 2014:617868. https://doi.org/10.1155/2014/617868.

25. Hanahan D, Weinberg RA. Hallmarks of cancer: the next generation. Cell. 2011; 144:646-74. https://doi. org/10.1016/j.cell.2011.02.013.

26. Shen H, Zhu F, Liu J, Xu T, Pei D, Wang R, Qian Y, Li Q, Wang L, Shi Z, Zheng J, Chen Q, Jiang B, Shu Y. Alteration in Mir-21/PTEN expression modulates gefitinib resistance in non-small cell lung cancer. PLoS One. 2014; 9:e103305. https://doi.org/10.1371/journal.pone.0103305.

27. Brambilla E, Negoescu A, Gazzeri S, Lantuejoul S, Moro D, Brambilla C, Coll JL. Apoptosis-related factors p53, $\mathrm{Bcl} 2$, and Bax in neuroendocrine lung tumors. Am J Pathol. 1996; 149:1941-52.

28. Borchert S, Czech-Sioli M, Neumann F, Schmidt C, Wimmer P, Dobner T, Grundhoff A, Fischer N. Highaffinity $\mathrm{Rb}$ binding, p53 inhibition, subcellular localization, and transformation by wild-type or tumor-derived shortened Merkel cell polyomavirus large T antigens. J Virol. 2014; 88:3144-60. https://doi.org/10.1128/JVI.02916-13.

29. Ma X, Choudhury SN, Hua X, Dai Z, Li Y. Interaction of the oncogenic miR-21 microRNA and the p53 tumor suppressor pathway. Carcinogenesis. 2013; 34:1216-23. https://doi.org/10.1093/carcin/bgt044.

30. Wu DW, Tsai LH, Chen PM, Lee MC, Wang L, Chen CY, Cheng YW, Lee H. Loss of TIMP-3 promotes tumor invasion via elevated IL-6 production and predicts poor survival and relapse in HPV-infected non-small cell lung cancer. Am J Pathol. 2012; 181:1796-806. https://doi. org/10.1016/j.ajpath.2012.07.032.

31. Ye G, Fu G, Cui S, Zhao S, Bernaudo S, Bai Y, Ding Y, Zhang Y, Yang BB, Peng C. MicroRNA 376c enhances ovarian cancer cell survival by targeting activin receptorlike kinase 7: implications for chemoresistance. J Cell Sci. 2011; 124:359-68. https://doi.org/10.1242/jcs.072223.

32. El-Badrawy MK, Yousef AM, Shaalan D, Elsamanoudy AZ. Matrix metalloproteinase-9 expression in lung cancer patients and its relation to serum mmp-9 activity, pathologic type, and prognosis. J Bronchology Interv Pulmonol. 2014; 21:327-34. https://doi.org/10.1097/ LBR.0000000000000094.

33. Li J, Wang H, Ke H, Ni S. MiR-129 regulates MMP9 to control metastasis of non-small cell lung cancer. Tumour Biol. 2015; 36:5785-90. https://doi.org/10.1007/s13277-015-3247-z.

34. Lowenstein EJ, Daly RJ, Batzer AG, Li W, Margolis B, Lammers R, Ullrich A, Skolnik EY, Bar-Sagi D, Schlessinger J. The SH2 and SH3 domain-containing protein GRB2 links receptor tyrosine kinases to ras signaling. Cell. 1992; 70:43142. https://doi.org/10.1016/0092-8674(92)90167-B.

35. Li J, Bennett K, Stukalov A, Fang B, Zhang G, Yoshida T, Okamoto I, Kim JY, Song L, Bai Y, Qian X, Rawal B, Schell M, et al. Perturbation of the mutated EGFR interactome identifies vulnerabilities and resistance mechanisms. Mol Syst Biol. 2013; 9:705. https://doi. org/10.1038/msb.2013.61.

36. Sachdeva M, Zhu S, Wu F, Wu H, Walia V, Kumar S, Elble $\mathrm{R}$, Watabe K, Mo YY. p53 represses c-Myc through induction of the tumor suppressor miR-145. Proc Natl Acad Sci USA. 2009; 106:3207-12. https://doi.org/10.1073/pnas.0808042106.

37. Chiou GY, Cherng JY, Hsu HS, Wang ML, Tsai CM, Lu KH, Chien Y, Hung SC, Chen YW, Wong CI, Tseng LM, Huang PI, Yu CC, et al. Cationic polyurethanes-short branch PEImediated delivery of Mir145 inhibited epithelial-mesenchymal transdifferentiation and cancer stem-like properties and in lung adenocarcinoma. J Control Release. 2012; 159:240-50. https:// doi.org/10.1016/j.jconrel.2012.01.014.

38. Hervouet E, Cheray M, Vallette FM, Cartron PF. DNA methylation and apoptosis resistance in cancer cells. Cells. 2013; 2:545-73. https://doi.org/10.3390/cells2030545.

39. Võsa U, Vooder T, Kolde R, Vilo J, Metspalu A, Annilo T. Meta-analysis of microRNA expression in lung cancer. Int $\mathrm{J}$ Cancer. 2013; 132:2884-93. https://doi.org/10.1002/ijc.27981.

40. Guo C, Shao R, Correa AM, Behrens C, Johnson FM, Raso MG, Prudkin L, Solis LM, Nunez MI, Fang B, Roth JA, Wistuba II, Swisher SG, et al. Prognostic significance of combinations of RNA-dependent protein kinase and EphA2 biomarkers for NSCLC. J Thorac Oncol. 2013; 8:301-08. https://doi.org/10.1097/JTO.0b013e318282def7.

41. Andres C, Belloni B, Puchta U, Sander CA, Flaig MJ. Prevalence of MCPyV in Merkel cell carcinoma and nonMCC tumors. J Cutan Pathol. 2010; 37:28-34. https://doi. org/10.1111/j.1600-0560.2009.01352.x.

42. Peltier HJ, Latham GJ. Normalization of microRNA expression levels in quantitative RT-PCR assays: identification of suitable reference RNA targets in normal and cancerous human solid tissues. RNA. 2008; 14:844-52. https://doi.org/10.1261/rna.939908.

43. Yan B, Li H, Yang X, Shao J, Jang M, Guan D, Zou S, Van Waes C, Chen Z, Zhan M. Unraveling regulatory programs for NF-kappaB, p53 and microRNAs in head and neck squamous cell carcinoma. PLoS One. 2013; 8:e73656. https://doi.org/10.1371/journal.pone.0073656.

44. Mima K, Nishihara R, Nowak JA, Kim SA, Song M, Inamura K, Sukawa Y, Masuda A, Yang J, Dou R, Nosho K, Baba H, Giovannucci EL, et al. MicroRNA MIR21 and T Cells in Colorectal Cancer. Cancer Immunol Res. 2016; 4:33-40.

45. Liu LZ, Li C, Chen Q, Jing Y, Carpenter R, Jiang Y, Kung HF, Lai L, Jiang BH. MiR-21 induced angiogenesis through AKT and ERK activation and HIF-1 $\alpha$ expression. PLoS One. 2011; 6:e19139. https://doi.org/10.1371/journal.pone.0019139.

46. Ruan Q, Wang T, Kameswaran V, Wei Q, Johnson DS, Matschinsky F, Shi W, Chen YH. The microRNA21-PDCD4 axis prevents type 1 diabetes by blocking pancreatic beta cell death. Proc Natl Acad Sci USA. 2011; 108:12030-35. https://doi.org/10.1073/pnas.1101450108. 